http://dx.doi.org/10.12775/szhf.2019.019

\author{
WOJCIECH WŁOCH \\ Uniwersytet MikoŁaja Kopernika, Toruń, Polska \\ ORCID: 0000-0003-0807-5130 \\ E-MAIL:WLOCH@UMK.PL
}

\title{
Emotywizm jako metaetyczny fundament pozytywizmu prawnego w ujęciu czystej teorii prawa Hansa Kelsena
}

Teza, iż obowiązywanie prawa nie jest uzależnione od jego wartości moralnej, jest jednym z fundamentów pozytywizmu prawnego. Przedmiotem niniejszego artykułu są argumenty metaetyczne uzasadniające tę tezę, sformułowane w ramach czystej teorii prawa Hansa Kelsena. Identyfikacja argumentów metaetycznych pozwala odpowiedzieć na pytania, jaka wizja moralności leży u podstaw pozytywizmu (czy też jednej z jego wersji) oraz dlaczego zgodnie z tym stanowiskiem nie należy jej łączyć z prawem. W tym celu w części pierwszej analizuję zagadnienie sprawiedliwości prawa z perspektywy teorii Kelsena. Stosunek do tej kwestii pozwala wyodrębnić dwie formy nauki prawa (część druga). Następnie omawiam przesłanki odrzucenia przez pozytywizm norm moralnych jako podstawy ważności norm prawnych. Dalej wskazuję, iż metaetycznym fundamentem czystej teorii prawa w badanym aspekcie jest emotywizm. Na końcu zaś rozważam kwestię, czy w jej ramach można wskazać jakąś wartość pozaprawną stanowiącą „moralne minimum” prawa. 


\section{Czy prawo powinno być sprawiedliwe?}

Sprawiedliwość jest podstawowym i powszechnym wymaganiem etycznym wysuwanym wobec prawa. Jednakże z punktu widzenia czystej teorii prawa Hansa Kelsena taki postulat jest kłopotliwy ze względu na charakter samej „sprawiedliwości”. Przypisywana jednostce właściwość lub cnota sprawiedliwości, jak twierdzi Kelsen, wyraża się w zachowaniach wobec innych osób, tj. w zachowaniach społecznych. „Społeczne zachowanie pewnego człowieka jest sprawiedliwe, jeżeli jest zgodne z pewną normą, która je nakazuje, tzn. ustanawia jako powinność i przez to konstytuuje wartość sprawiedliwościową (Gerechtigkeitswert)"1. W takim ujęciu sprawiedliwość polega na zgodności zachowania z normą konstytuującą „wartość sprawiedliwościową”. Podstawą wartościowania jest owa norma, a więc można powiedzieć, że „wartości sprawiedliwościowe” opierają się na „normie sprawiedliwościowej”: zgodnie z normą ocenia się czyn i przypisuje mu pewną wartość. Specyfika „norm sprawiedliwościowych” polega - zdaniem autora Reine Rechtslehre na tym, że dotyczą one społecznych zachowań ludzi². Sprawiedliwość jest właśnie właściwością ludzkich zachowań ujmowanych z perspektywy tych norm. Umożliwiają one wydanie sądu, który określa, czy dane zachowanie jest sprawiedliwe, tzn. sądu oceniającego. Ocena dotyczy pewnego działania, a więc faktu. W konsekwencji tylko faktom, tj. społecznym interakcjom i działaniom, można przypisać lub odmówić wartość bycia sprawiedliwymi³.

${ }^{1}$ Hans Kelsen, „Das Problem der Gerechtigkeit”, w: Hans Kelsen, Reine Rechtslehre (zweite Auflage) mit einem Anhang Das Problem der Gerechtigkeit (Wien: Verlag Franz Deuticke, 1967), 357.

${ }^{2}$ Tamże, 357. Kelsen pojmuje sprawiedliwość szeroko. Zgodnie z podziałem Kazimierza Ajdukiewicza szczególny nacisk kładzie na sprawiedliwość legalną polegającą na zgodności z ideą prawa, ale odnosi się także do sprawiedliwości jako moralnej słuszności, np. przy rozważaniu istoty sądów moralnych, por. Kazimierz Ajdukiewicz, „O sprawiedliwości”, w: Kazimierz Ajdukiewicz, Język i poznanie, tom I (Warszawa: Państwowe Wydawnictwo Naukowe, 1985), 368. Natomiast sprawiedliwość jako zgodność z literą prawa (legalność) uznaje za jedyną formę sprawiedliwości dopuszczalną w ramach nauki prawa, por. Hans Kelsen, General Theory of Law and State, transl. Anders Wedberg (Cambridge: Harvard University Press, 1949), 14.

${ }^{3}$ Kelsen, „Das Problem der Gerechtigkeit”, 358. 
Czy zatem pytanie o sprawiedliwość prawa jest bezprzedmiotowe? Czy przyjmując za kryterium „normy sprawiedliwościowe”, nie można poddawać ocenie innych norm, np. oceniać norm prawnych jako sprawiedliwych lub niesprawiedliwych? Zakładałoby to równoczesne obowiązywanie norm prawnych i „norm sprawiedliwościowych”. Kelsen twierdzi, że gdy obydwa rodzaje norm uznajemy za ważne (obowiązujące), prowadzi to do konfliktu (nie należy go rozumieć jako sprzeczności logicznej), tylko bowiem jeden rodzaj norm można uznać za ważny ${ }^{4}$. Inaczej mówiąc, uznanie norm sprawiedliwościowych za obowiązujące oznacza, iż nie obowiązują normy prawne, i odwrotnie. Kelsen wychodzi z antynaturalistycznego założenia, że właściwością norm jest obwiązywanie albo nieobowiązywanie, a nie prawda lub fałsz ${ }^{5}$. Subiektywnym znaczeniem norm jest zachowanie określone $\mathrm{w}$ ich treści, znaczeniem obiektywnym jest to, że obowiązują, tj. wiążą adresatów niezależnie od ich indywidualnego do nich stosunku' ${ }^{6}$. Jeżeli dane zachowanie $Z$ norma prawna $N p$ określa jako nakazane, a norma sprawiedliwościowa

\footnotetext{
${ }^{4}$ Tamże.
}

${ }^{5}$ Stanowisko antynaturalistyczne uznaje, że „zdania etyczne są nieredukowalne do zdań empirycznych ani do zdań innego rodzaju, takich jak zdania z dziedziny teologii lub matematyki”, John Hospers, „Główne teorie metaetyczne”, przeł. Ewa Klimowicz, w: Metaetyka, red. Ija Lazari-Pawłowska (Warszawa: Państwowe Wydawnictwo Naukowe, 1975), 40. Używanie pojęć i kategorii z dziedziny wiedzy faktualnej do opisu i wyjaśniania podstawowych zasad moralności jest, jak twierdzi George E. Moore, „błędem naturalistycznym”, por. George E. Moore, Principia Ethica (Cambridge: Cambridge Univerity Press, 1993), 65. Por. też Alfred J. Ayer, Filozofia w XX wieku, przeł. Tadeusz Baszniak (Warszawa: Wydawnictwo Naukowe PWN, 1997), 57. „Jeśli istnieje jakiś »błąd naturalistyczny« - pisze Aalfred J. Ayer - to polega on na definiowaniu »dobra « w taki sposób, który nie implikuje, że to, co dobre, jest czymś, do czego należy dążyć, lub czymś, co winno zostać wykonane. Polega on, krótko mówiąc, na zignorowaniu normatywnego aspektu dobra. Jeśli jest tak w istocie, argument Moore’a jest tylko echem formuły Hume’a, że nie można wywieść "powinien « $\mathrm{z}$ »jest «. Wychodzi od przesłanki, że »dobro « jest słowem normatywnym, a następnie wyprowadza słuszny wniosek, że błędem musi być usiłowanie nadawania mu czysto opisowego znaczenia”, tamże, 61. Jak zauważa William K. Frankena, zwolennicy takiego poglądu twierdzą, że naturaliści popełniają „błąd definicyjny", albowiem ustalając definicję kategorii etycznych poprzez kategorie naturalne (fakty, prawidłowości psychologiczne lub społeczne itp.), utożsamiają właściwości z dwóch odmiennych dziedzin, William K. Frankena, “The Naturalistic Fallacy”, Mind. New Series 48/192 (1939): 471.

${ }^{6}$ Normy obowiązują, jeżeli „zakładamy, że jednostki, których zachowanie jest regulowane przez normy, "powinny« zachowywać się w sposób przepisany przez normy", Kelsen, General Theory of Law and State, 112. Obowiązywanie normy oznacza, że jest wiążąca (verbindlich), 
Ns jako zakazane, to w sensie obiektywnym może obowiązywać tylko jedna $\mathrm{z}$ nich, tj. albo $N p$, albo $N s$. W przypadku gdy oceniamy $N p$ w odniesieniu do $N s$ i stwierdzamy, że $N p$ jest „niesprawiedliwa” z uwagi na Ns, to faktycznie stwierdzamy, że $Z$ jest niezgodne z $N s$, natomiast zgodne z $N p$. Uznając, że z powodu niezgodności z Ns norma Np nie obowiązuje, stwierdzamy w istocie wyłączne obowiązywanie Ns. Odwrotnie: stwierdzając, że pomimo sprzeczności z Ns obowiązuje norma $N p$, uznajemy $N s$ za niewiążącą. Dlatego Kelsen twierdzi, iż obowiązywać obiektywnie może tylko jeden system norm $^{7}$. Kwestia dotyczy samego obowiązywania norm sprawiedliwościowych i prawnych, a nie oceny ich wartości. Zgodnie z przyjętym wyżej stanowiskiem, norma nie może być osądzana pod kątem jej wartości, ta bowiem jest właściwością faktów ocenianych z uwagi na pewne normy. To nie normy są przedmiotem sądu wartościującego, lecz fakty. Z tego powodu konflikt norm jest wynikiem odmiennej oceny tego samego typu zachowania. Toteż w konflikt z Ns mogłaby wchodzić nie tyle sama $N p$, ile działania ustanawiające $N p$, której treścią jest uznanie $Z$ za nakazane, gdy $N$ s uznaje je za zakazane ${ }^{8}$.

Odmienność w ujmowaniu stosunku norm sprawiedliwościowych do norm prawnych konstytuuje istotną różnicę między pozytywizmem a kon-

tj. „człowiek powinien zachowywać się w sposób określony przez normę”, Hans Kelsen, Czysta teoria prawa, przeł. Rafał Szubert (Warszawa: LexisNexis, 2014), 295.

${ }^{7}$ Kelsen, „Das Problem der Gerechtigkeit”, 359.

${ }^{8}$ „Wedle interpretacji samego Kelsena, stwierdzenie, że dana osoba pozostaje w konflikcie obowiązków, jest tylko i wyłącznie stwierdzeniem faktycznym, podobnym do stwierdzenia, że na ten sam punkt działają dwie siły przeciwnie skierowane. Nie jest to w szczególności kwestia relacji między znaczeniem norm czy zdań powinnościowych. Konflikt w tym rozumieniu jest więc dopuszczalny, a psychologowie i socjologowie rzeczywiście wypowiadają takie stwierdzenia”, Herbert L. A. Hart, „Wizyta u Kelsena”, w: Herbert L. A. Hart, Eseje z filozofii prawa, przeł. Jan Woleński (Warszawa: Dom Wydawniczy ABC, 2001), 309. Hart uważa, że stanowisko powyższe jest błędne. „Aby wykryć, czy taki konflikt ma w danym przypadku miejsce, czy też nie, musimy rozważyć znaczenie przepisu prawnego i reguły moralnej, traktując je w tym kontekście jako (wedle terminologii Kelsena) zdania powinnościowe”, tamże, 310. Prawo i moralność mogą nakazywać przeciwstawne obowiązki, a przyjęcie ważności obydwu nie prowadzi do sprzeczności, bo można sensownie wyrazić obowiązywanie dwóch norm prowadzących do wykluczających się obowiązków. Konflikt polegałby natomiast na tym, że dana osoba nie może spełniać tego typu dwóch norm, a nie na tym, że nie można stwierdzić ich równoczesnej ważności. 
cepcjami prawno-naturalnymi ${ }^{9}$. Rozbieżność nie dotyczy treści norm, albowiem zarówno $N p$, jak i $N s$ mogą w ten sam sposób oceniać $Z$. Polega natomiast na uzasadnieniu ważności norm. Pozytywizm nie wiąże ważności norm prawnych $\mathrm{z}$ normami sprawiedliwościowymi $(N p \neq N s)$, natomiast stanowisko prawno-naturalne ściśle łączy je ze sobą $(N p=N s)^{10}$. Z perspektywy pozytywizmu obowiązywanie $N p$ jest niezależne od zgodności z $N s$. $\mathrm{W}$ przypadku gdy $Z$ jest pozytywnie wartościowanie zarówno z uwagi na Ns, jak i $N p$, to nie tyle $N p$ jest sprawiedliwa, ile raczej $Z$ jest sprawiedliwe. Obydwie normy należą do odmiennych systemów normatywnych. Zgodność lub niezgodność $N p$ z $N s$ nie wpływa na ważność $N p^{11}$. Inaczej mówiąc: w ramach teorii pozytywistycznej podstawą legitymizacji ważności $N p$ nie jest zgodność $\mathrm{z} \mathrm{Ns}^{12}$, natomiast w ramach teorii prawno-naturalnej zbiór norm $N p$ w zasadzie zawiera się w zbiorze norm Ns. Kelsen wskazuje, że istota stanowiska

${ }^{9}$ Walter Ott określa pozytywizm jako teorię podnoszącą postulat niezależności prawa od metafizyki oraz moralności (rozróżnienie prawa na takie, jakie jest i jakie być powinno), o tendencji relatywistycznej, Walter Ott, Der Rechtspositivismus. Kritische Würdigung auf der Grundlage eines juristischen Pragmatismus (Berlin: Duncker und Humblot, 1976), 28-29. Pozytywizm to teoria, która unikając metafizycznych założeń, określa pojęcie prawa za pomocą pewnych neutralnych aksjologicznie cech, tamże, 102-103. Cechy pozytywizmu to niezależność od metafizycznych założeń; nastawienie na prawo rzeczywiste; odróżnienie prawa od moralności, tamże, 103. Należy pamiętać, że teza o niezależności dotyczy pojęcia prawa, a nie treści, ponieważ nie sposób zaprzeczyć, że idee moralne wpływają na treść prawa i odwrotnie. Natomiast „rzetelna teoria prawa naturalnego to teoria, która otwarcie [...] podejmuje krytykę praktycznych punktów widzenia, aby odróżnić stanowiska praktycznie rozumne od nierozumnych [...]. Teoria prawa naturalnego utrzymuje, że potrafi rozpoznać warunki i zasady trafnego osądu praktycznego, dobrego i właściwego porządku zarówno w relacjach między ludźmi, jak i w postępowaniu jednostki”, John Finnis, Prawo naturalne i uprawnienia naturalne, przeł. Karolina Lossman (Warszawa: Dom Wydawniczy ABC, 2001), 24.

${ }_{10}$ Zdaniem Johna Finnisa teza Kelsena, iż prawo pozytywne jest „kopią” prawa naturalnego, stanowi o niezrozumieniu teorii prawno-naturalnych. Prawo stanowione jest niezbędne z dwóch powodów: „po pierwsze, samo prawo naturalne nie dostarcza wszystkich ani nawet większości rozwiązań potrzebnych do koordynacji życia wspólnotowego", po drugie, z uwagi na „konieczność przymusu - zmuszenie egoistów, by postępowali w sposób racjonalny”, tamże, 36-37. Ujęcie Kelsena można by było sprowadzić do tezy, że teorie prawa naturalnego czynią prawo stanowione redundantnym, co - jak słusznie wskazuje Finnis - prowadzi do ich karykatury. Teorie prawa naturalnego lepiej wyraża formuła związku między $N s$ i $N p(N s \rightarrow N p)$ aniżeli zrównanie $N p$ do $N s$.

${ }^{11}$ Kelsen, „Das Problem der Gerechtigkeit”, 360-361.

12 Tamże, 362. 
pozytywistycznego wyraża się w twierdzeniu o niezależności obowiązywania norm prawa pozytywnego od norm sprawiedliwościowych ${ }^{13}$, dlatego zasadę niezależności określić można jako zasadę pozytywizmu ${ }^{14}$. Pozytywizm, pytając o obiektywny sens norm (tj. o ich ważność), nie wychodzi poza system norm prawnych.

\section{Dualistyczna i monistyczna nauka prawa}

Na podstawie rozróżnienia norm sprawiedliwościowych i prawnych Kelsen wprowadza podział na dualistyczną (idealistyczną) i monistyczną (realistyczną) naukę prawa ${ }^{15}$. Ścisłe powiązanie ważności prawa pozytywnego ze zgodnością z normami sprawiedliwościowymi musi zakładać obiektywny charakter tych drugich, co jest cechą stanowisk dualistycznych (idealistycznych). Obiektywna ważność określonej normy sprawiedliwościowej wykluczałaby ważność wszelkich norm z nią niezgodnych. Niemniej jednak kon-

\footnotetext{
13 Tamże, 360.

14 Tamże, 362. Herbert L. A. Hart wyróżnia pięć znaczeń pozytywizmu: (1) twierdzenie, że prawa są nakazami istot ludzkich; (2) twierdzenie, że nie ma koniecznego związku między prawem a moralnością lub prawem takim, jakie jest i powinno być; (3) twierdzenie, że analiza (lub badanie znaczenia) pojęć prawnych jest (a) warta prowadzenia i (b) należy ją odróżnić od badań historycznych i socjologicznych oraz od krytyki lub oceny prawa pod względem moralności, celów społecznych itp.; (4) twierdzenie, że system prawny jest „zamkniętym systemem logicznym", w którym prawidłowe decyzje prawne można wywnioskować za pomocą logicznych środków z góry określonych zasad prawnych, bez odniesienia do celów społecznych, polityki, norm moralnych; (5) twierdzenie, że sądów moralnych nie można ustalić i bronić poprzez racjonalne argumenty i dowody tak, jak można bronić twierdzeń dotyczących faktów („nonkognitywizm” w etyce), Herbert L. A. Hart, "Positivism and the Separation of Law and Morals", Harvard Law Review 71/4 (1958): 601-602 [przypis]. Jan Woleński zauważa, że „najmocniej [...] Hart podkreśla swój związek z pozytywizmem w kwestii stosunku prawa i moralności”, Jan Woleński, „Wstęp”, w: Herbert L. A. Hart, Pojęcie prawa, przeł. Jan Woleński (Warszawa: Wydawnictwo Naukowe PWN, 1998), XIII-XIV.

${ }^{15}$ Kelsen, „Das Problem der Gerechtigkeit“, 402 i nast. Por. Wojciech Włoch, „Normatywny charakter nauk prawnych w świetle czystej teorii prawa H. Kelsena”, Ruch Filozoficzny 4 (2013): 767-773 [ostatnie zdanie artykułu dodane przez redakcję „Ruchu Filozoficznego”]. Szeroko o normatywizmie Kelsena por. Monika Zalewska, Problem zarachowania w normatywizmie Hansa Kelsena (Łódź: Wydawnictwo Uniwersytetu Łódzkiego, 2014), 19-68.
} 
statacja wielości koncepcji sprawiedliwości, a co za tym idzie wielości norm sprawiedliwościowych, jak też faktu, że mogą ze sobą kolidować, może prowadzić do tezy o ich relatywnym charakterze ${ }^{16}$. Monizm głosi, iż ważność norm prawa pozytywnego jest niezależna od jego zgodności z normami pozaprawnymi, co można uzasadniać relatywnością norm sprawiedliwościowych ${ }^{17}$. Dla stwierdzenia ważności (obowiązywania) normy prawnej nie jest konieczne badanie jej zgodności z normami innymi niż prawne, gdyż wystarczy stwierdzenie, iż jej ustanowienie jest legitymizowane przez normę wyższego $\mathrm{rzędu}^{18}$. Ewentualna ocena treści nie miałaby znaczenia dla rozstrzygnięcia jej obowiązywania. Głównym postulatem realistycznej nauki prawa jest wyrzeczenie się przez naukę prawa skłonności do oceniania norm prawnych i skupienie się wyłącznie na ich opisie ${ }^{19}$.

Przyjęcie stanowiska monistycznej lub dualistycznej nauki prawa opiera się w zasadzie na tym, czy przypisujemy normom sprawiedliwościowym subiektywną (relatywną) lub obiektywną ważność. Z punktu widzenia teorii relatywistycznej osąd prawa wiąże się z koniecznością wyboru przez oceniającego normy sprawiedliwościowej spośród wielu norm i koncepcji. Ostatecznie decyzja zależy od jednostki oceniającej ${ }^{20}$. Zdaniem Kelsena konieczność

${ }^{16}$ Kelsen rozróżnia metafizyczny i racjonalny typ norm sprawiedliwościowych, por. Kelsen, „Das Problem der Gerechtigkeit”, lecz żadnego z typów nie można sprawdzić do jednej formy.

${ }^{17}$ Por. tamże, 403.

${ }^{18}$ Jest to jedna $\mathrm{z}$ fundamentalnych tez czystej teorii prawa: warunkiem obowiązywania pewnej normy prawnej jest obowiązywanie innej normy prawnej, która reguluje sposób utworzenia tej pierwszej, druga norma stanowi bezpośrednią podstawę obowiązywania pierwszej, por. Hans Kelsen, Reine Rechtslehre (zweite Auflage) mit einem Anhang Das Problem der Gerechtigkeit (Wien: Verlag Franz Deuticke, 1967), 228; Kelsen, Czysta teoria prawa, 335. Stosunek pomiędzy normą „warunkującą” a „uwarunkowaną” można określić jako nadrzędny i podrzędny, w którym „norma regulująca tworzenie jest normą wyższą, norma utworzona zgodnie z ustanowieniem jest normą niższą", tamże. Pełnego znaczenia obiektywnego norma nabywa dopiero wtedy, gdy staje się częścią systemu norm, por. Ota Weinberger, Normentheorie als Grundlage der Jurisprudenz und Ethik. Eine Auseinandersetzung mit Hans Kelsens Theorie der Normen (Berlin: Duncker und Humblot, 1981), 130.

${ }^{19}$ Kelsen, „Das Problem der Gerechtigkeit“, 404.

${ }^{20} \mathrm{Na}$ tym polega - twierdzi Kelsen - autonomia moralna jednostki, oznaczająca, że „zastosowanie ogólnych norm do konkretnego przypadku może nastąpić tylko poprzez normę indywidualną, którą jednostka kieruje wobec siebie w uznaniu ogólnej normy moralnej, lub jeśli inny [podmiot] uzna dane zachowanie za zgodne lub niezgodne $\mathrm{z}$ generalną normą", Hans Kelsen, Allgemeine Theorie der Normen (Wien: MANZ Verlag, 1979), 38. Jej wyrazem jest 
wyboru normy będącej podstawą wartościowania stanowi o „prawdziwym sensie autonomii moralnej”21. Sąd dotyczący wartości należy do wyłącznej kompetencji jednostki (usytuowanej w określonym kontekście) i tylko ona ostatecznie za niego odpowiada (nawet jeżeli na jej decyzję wpływa np. kultura, w której funkcjonuje). Monizm jest realistyczny, przekonuje Kelsen, ogranicza się bowiem do poznania i opisu norm ustanowionych w ramach określonego systemu prawnego, natomiast dualizm niejako duplikuje prawo, traktując prawo pozytywne jako „odbicie”, czy też „przejaw”, prawa idealnego (naturalnego, rozumowego) ${ }^{22}$. Realizm teorii monistycznej polega na tym, że jej przedmiotem jest prawo ustanowione przez określony akt ludzkiej woli (np. odpowiedni organ), a nie takie, które musi dowieść swojej „prawdziwości” lub „słuszności” poprzez odniesienie do pewnego transcendentnego systemu normatywnego. Realizm traktuje prawo pozytywne jako wykreowane przez specyficzną ludzką aktywność (np. ustanowione przez legislację, zwyczaj, precedensy), natomiast idealizm jako reprodukcję prawa „wyższego" (prawa boskiego, rozumowego, naturalnego) ${ }^{23}$.

\section{Emotywny charakter norm sprawiedliwościowych}

Odrzucenie dualistycznej nauki prawa przez pozytywizm uzasadnia się tym, że sądy sprawiedliwościowe nie odnoszą się do obiektywnie ważnych norm. Ich podstawową funkcją nie jest też przekazywanie informacji. Wyrażają one - twierdzi Kelsen - przede wszystkim emocje wypowiadającego. Wypowiedzi wyrażające osąd danego stanu rzeczy, wydane z uwagi na normę sprawiedliwościową (czy szerzej - moralną), mają charakter emotywny. „Wedle emotywizmu wypowiedzi te nie mają stwierdzać faktów; nie są zazwy-

uznanie lub recepcja norm już ustanowionych, por. Weinberger, Normtheorie als Grundlage der Jurisprudenz und Ethik, 143.

${ }^{21}$ Kelsen, „Das Problem der Gerechtigkeit”, 442.

${ }^{22}$ Kelsen wskazuje, że dualizm stanowi pozostałość myślenia animistycznego, por. Hans Kelsen, "Law, State and Justice in the Pure Theory of Law", The Yale Law Journal 57/3 (1948): 377.

${ }^{23}$ Tamże, 386. 
czaj formułowane w celu przekazywania informacji. Służą one, po pierwsze, do tego, by wpływać na zachowanie innych ludzi: gdy ktoś mówi »nie powinieneś tego robić«, to próbuje powstrzymać drugą osobę od robienia tego. Po drugie, wypowiedzi te służą do wyrażenia (nie do opisu) postawy mówiącego" ${ }^{24}$. Kelsen określa normy sprawiedliwościowe jako normy moralne odniesione do sfery społecznej. Dla wyznaczenia ich roli w nauce prawa istotne jest rozstrzygnięcie kwestii, czy sądy moralne są możliwe czy niemożliwe do racjonalnego uzasadnienia, a więc czy mogą stanowić obiektywną podstawę ważności norm prawnych.

Sądy sprawiedliwościowe nie są oczywiście całkowicie puste informacyjnie. Nawiązując do koncepcji sądów etycznych Alfreda J. Ayera, można powiedzieć, że chociaż „zawierają” one wyrażenia deskryptywne (np. opis działania), nie oznacza to, iż można je do nich sprowadzić. Emotywizm nie prowadzi też do stanowiska głoszącego, że wartości nie można porównywać i ujednolicać. Można to robić, jednakże nie ma obiektywnego wzoru rozwiązywania sporów między nimi ani obiektywnej miary ich ważności. „Zdania, które zawierają normatywne etyczne symbole, nie są ekwiwalentami zdań wyrażających psychologiczne sądy czy też sądy empiryczne dowolnego rodzaju” 25 , np. „X pożąda stanu rzeczy $Y$ ” nie oznacza, że „Y jest dobre lub słuszne"26. Zawarte $\mathrm{w}$ wypowiedziach sprawiedliwościowych symbole etyczne o znaczeniu normatywnym są nieredukowalne do terminów faktualnych. „Obecność etycznego symbolu w zdaniu nic nie dodaje do jego faktualnej treści”27. Faktualne znaczenie zdań „źle, że ukarałeś $Y$ ” i „ukradłeś $Y$ ” jest takie samo. Symbol etyczny dodaje w pierwszym zadaniu tylko dezaprobatę wobec danego faktu, inaczej: wyraża uczucia mówiącego. Uogólnienie danego sądu etycznego „kradzież jest zła” nie może być rozpatrywane jako prawdziwe lub fałszywe. Zdaniem Ayera jest to tylko wyrażenie pewnego moralnego uczucia. Zdanie „kradzież nie jest zła” nie byłoby sprzeczne z poprzednim, lecz stanowiłoby wyrażenie innego uczucia. Relewantną funkcją

\footnotetext{
${ }^{24}$ James Rachels, „Subiektywizm”, przeł. Anna Jedynak, w: Przewodnik po etyce, red. Peter Singer (Warszawa: Książka i Wiedza, 2009), 485.

${ }_{25}$ Alfred J. Ayer, Language, Truth and Logic (New York: Dover Publications, 1952), 105.

${ }^{26}$ Nie wyklucza to możliwości deskryptywnego użycia symboli etycznych, np. „Y jest złe”, jako opisujących postawy etyczne danego społeczeństwa, np. przez socjologię.

${ }_{27}$ Ayer, Language, Truth and Logic, 107.
} 
etycznego symbolu użytego w sądzie sprawiedliwościowym jest funkcja czysto „emotywna” 28 . Używa się go w celu wyrażenia uczuć dotyczących pewnego stanu rzeczy, a nie formułowania twierdzeń na jego temat ${ }^{29}$. Teza, iż nie można podać obiektywnego kryterium ważności sądów etycznych, wynika więc z konstatacji ich subiektywnego znaczenia. „Zdania, które po prostu wyrażają sądy moralne, nic nie mówią. Są czystymi ekspresjami uczuć i jako takie nie podpadają pod kategorie prawdy i fałszu. Są nieweryfikowalne z tego samego powodu co płacz lub ból czy rozkaz, dlatego że nie wyrażają prawdziwych twierdzeń (genuine propositions)"30. Emotywizm można określić mianem radykalnego subiektywizmu: sądy etyczne nie „opisują” uczuć (opis może być prawdziwy lub fałszywy), lecz „wyrażają” je (obydwa wymiary mogą się realnie zbiegać, czy też zdanie może zawierać obydwa wymiary deskryptywny i emotywno-normatywny). $Z$ takiego punktu widzenia sądom etycznym nie można przypisać żadnej obiektywnej ważności ${ }^{31}$.

Biorąc pod uwagę powyższe rozważania, można zapytać, czy każdy spór o sprawiedliwość treści prawa (jeżeli wykluczamy aspekt jego ważności) byłby irracjonalny. Według Ayera dyskusje, które uważamy za etyczne, w rzeczywistości nimi nie są. Spieramy się raczej o fakty wpływające na przyjmowane przez nas sądy etyczne (zdarzenia, uwarunkowania, konsekwencje). Wskazujemy na nie po to, by zmienić nastawienie interlokutora, wpłynąć na jego postawę, a nie po to, by wykazać, że jego sądy etyczne są „wadliwe”. W tym miejscu można wyrazić zastrzeżenie wobec twierdzenia o braku związku między sądami etycznymi a faktami, albowiem jeżeli moglibyśmy stwierdzić, że dana moralność lepiej współgra z konkretnymi uwarunkowaniami ekonomicznymi, politycznymi itp., to sądy moralne nie byłyby tylko i wyłącznie emotywne, lecz także funkcjonalnie powiązane z kontekstem społecznym. Zwolennik emotywizmu mógłby odpowiedzieć, że wskazujemy fakty, które „wpływają” na zasady i wartości, a nie fakty „uzasadniające” je jako wartości. W danym kontekście $K_{1}$ jednostki zachowują się zgodnie z normami $N_{1}$,

\footnotetext{
${ }^{28}$ Tamże, 108.

${ }^{29}$ Jednakże terminy etyczne służą nie tylko do wyrażania uczuć, ale także do stymulowania pewnych działań (wzbudzania uczuć). Przez właściwe użycie terminów etycznych powinno uzyskać się ,efekt rozkazu”, tamże, 108.

30 Tamże, 108-109.

${ }^{31}$ Tamże, 110.
} 
w kontekście $K_{2}-$ z normami $N_{2}$. Ewentualne rozstrzygnięcie, które normy są słuszne (w sensie czysto normatywnym), wymagałoby przyjęcia niezależnej od kontekstualnego uwarunkowania normy $N_{3}$, a nie wskazania na pewien fakt. Z perspektywy emotywizmu istnienie takiej normy byłoby co najmniej kontrowersyjne ${ }^{32}$, a samo jej uznanie i tak zawsze będzie subiektywne. Ograniczenie dyskusji nad wartościami do wartości „najlepszych w danym kontekście” może prowadzić do wniosku, że rozważanie kwestii „sprawiedliwego prawa" nie ma sensu. Należałoby raczej zawęzić badania do określonego kontekstu (np. wolnorynkowa gospodarka jako $K_{1}$ ), aby wyrazić zalety danego prawa (np. określonego uregulowania prawa własności $N_{1}$ ). Jednakże nie będzie to nigdy uzasadnienie w ścisłym sensie (brak $N_{3}$ uzasadniającej $N_{1}$ ), lecz okreslenie pewnej korelacji i preferencji (współwystępowanie $\left.N_{1} \mathrm{z} K_{1}\right)^{33}$.

\section{Metaetyczna podstawa pozytywizmu prawnego}

Pozytywizm (monizm) w ujęciu Kelsena opiera się na emotywnej teorii moralności. Emotywizm jest teorią, którą z wielkim trudem dałoby się połączyć z tezą o istotnym związku moralności z prawem pozytywnym, ponieważ obiektywnej ważności prawa nie można oprzeć wyłącznie na zgodności $\mathrm{z}$ „wyrazem naszych uczuć”. Podstawa ważności norm prawnych musi być zatem inna aniżeli podstawa ważności norm moralnych, mająca radykalnie subiektywny charakter. Shia Moser uważa, że można wyróżnić trzy kategorie argumentów przeciwko tezie o istotnym związku między prawem a moralnością ${ }^{34}$ :

- argument metaprawny - brak rozróżnienia na prawo obowiązujące i takie, „jakie być powinno”, nauka prawa zajmuje się pierwszą kwestią;

\footnotetext{
32 Tamże, 112.

33 „Emotywizm utrzymuje więc, że potrafi objaśnić wszelkie możliwe sądy moralne. Gdyby więc teoria emotywizmu była prawdziwa, wszelkie sądy moralne byłyby nierozstrzygalne w racjonalny sposób", Alasdair MacIntyre, Dziedzictwo cnoty. Studium z teorii moralności, przeł. Adam Chmielewski (Warszawa: Wydawnictwo Naukowe PWN, 1996), 40; odnośnie do krytyki emotywizmu por. rozdział drugi i trzeci.

${ }^{34}$ Shia Moser, "Ethical Non-Cognitivism and Kelsen's Pure Theory of Law", The University of Toronto Law Journal 29/2 (1979): 94-95.
} 
- argument moralny - dotyczy szkodliwych konsekwencji społecznych i politycznych: teorie prawno-naturalne przedstawione są jako prowadzące do anarchii lub broniące status quo (określonych interesów politycznych oraz ekonomicznych);

- argument metaetyczny - odrzucenie założeń metafizycznych, epistemologicznych oraz doktryn etycznych wynikających z tych założeń, na których opierają się teorie praw naturalnych.

Argumenty powyższe są logicznie niezależne od siebie. Kelsen właściwie podnosi je wszystkie ${ }^{35}$. „Kelsen stosuje metaprawne i moralne argumenty przeciwko istotnemu związkowi między prawem a moralnością. Jednakże najmocniejszy motyw jego sprzeciwu wobec [twierdzeń - W. W.] o wszelkich takich powiązaniach jest związany z przynależnością do emotywnej teorii etyki”36. Sąd wartościujący (oceniający z uwagi na normę moralną) nie może być ani prawdziwy, ani fałszywy. Emotywizm twierdzi, że ważność takiego sądu ogranicza się do jednostki, która go wydaje ${ }^{37}$. Ważność w stosunku do innych jednostek poległaby na uznaniu przez nich jego ważności. $\mathrm{Z}$ tak za-

${ }^{35}$ Kelsen, Czysta teoria prawa, 134 i nast. Kelsen, "Law, State and Justice in the Pure Theory of Law", 386.

${ }^{36}$ Moser, "Ethical Non-Cognitivism and Kelsen's Pure Theory of Law", 101. Emotywizm zalicza się do niekognitywnych teorii etycznych. „Teorie nieemotywistyczne można nazwać kognitywistycznymi, ponieważ głoszą one, że wypowiedzi etyczne wyrażają prawdziwe lub fałszywe przekonania poznawcze”, Arthur Pap, „Teorie metaetyczne”, przeł. Ewa Klimowicz, w: Metaetyka, red. Ija Lazari-Pawłowska (Warszawa: Państwowe Wydawnictwo Naukowe, 1975), 22. W ramach teorii kognitywistycznych wyróżnić możemy teorie naturalistyczne i intuicjonistyczne. „Naturaliści opowiadają się za epistemologią logicznego empiryzmu, zgodnie z którym każde zdanie o charakterze poznawczym jest albo analityczne, albo empirycznie sprawdzalne. Natomiast intuicjoniści twierdzą, że pewne zdania etyczne są syntetycznymi zdaniami a priori”, tamże, 22. Teorie niekognitywistyczne głoszą, że „słowa wyrażające wartości nie mogą być właściwie zdefiniowane w terminach faktualnych", Moser, "Ethical NonCognitivism and Kelsen's Pure Theory of Law", 103.

${ }^{37}$ Teorii niekognitywistycznych nie należy zatem utożsamiać z twierdzeniem o niemożliwości uzasadnienia wypowiedzi normatywnych. „Ważną konsekwencją nonkognitywizmu dla praktycznego rozumowania jest fakt, że każde praktyczne uzasadnienie wymaga pewnych praktycznych argumentów, które wyrażają postawę oceniającą. Te przesłanki rozumowania można wyprowadzać $\mathrm{z}$ intuicji, z konsensusu, z wyraźnego porozumienia umownego lub z innych podobnych źródeł", Neil MacCormick, Ota Weinberger, An Institutional Theory of Law. New Approaches to Legal Positivism (Dordrecht-Boston-Lancaster-Tokyo: D. Reidel Publishing Company, 1992), 156. 
rysowanej perspektywy intersubiektywna ważność norm sprawiedliwościowych opierałaby się na ich wzajemnym uznaniu przez aktorów społecznych, a nie na ich obiektywnej i immanentnej słuszności.

Sąd: coś jest sprawiedliwe lub niesprawiedliwe - twierdzi Kelsen - jest sądem wartościującym odniesionym do pewnego najwyższego celu, a tego rodzaju sądy wartościujące mają ze swej istoty charakter subiektywny, ponieważ bazują na emocjonalnych elementach naszych umysłów, na naszych uczuciach i życzeniach. Nie można ich zweryfikować przez odniesienie do faktów, jak można to zrobić w przypadku sądów o rzeczywistości ${ }^{38}$.

Utożsamienie prawa ze sprawiedliwością stanowi sąd wartościujący, tj. oceniający dany system prawny jako sprawiedliwy. Przyjmując, że moralny sąd wartościujący wyraża tylko postawy mówiącego (czy też określonej grupy, jeżeli mówiący podsiada autorytet wypowiadania się w jej imieniu), należy powiedzieć, że tego typu sąd nie odznacza się obiektywną ważnością. „Rzeczywistym skutkiem terminologicznej identyfikacji prawa i sprawiedliwości jest niedopuszczalne usprawiedliwienie prawa pozytywnego"39, które stanowi jedynie wyraz preferowania określonych wartości.

W ramach Kelsenowskiej teorii prawa odrzucenie tezy o istotnym związku między prawem a moralnością łączy się z przyjęciem emotywistycznej etyki. Prawo pozytywne jest prawem ustanowionym, wykreowanym przez człowieka. Nauka prawa może opisać jedynie obowiązujące prawo („takie, jakie jest”), natomiast prawo postulowane („takie, jakie powinno być”) nie jest takim prawem (argument metaprawny). Emotywna teoria moralności odrzuca możliwość przyjęcia moralności jako kryterium ważności prawa, ponieważ sądy moralne mają charakter subiektywny i względny, $\mathrm{z}$ tego powodu prawo nie może stanowić „odbicia obiektywnego świata wartości” (argument metaetyczny). Uzależnienie ważności prawa od zgodności z normami sprawiedliwościowymi prowadziłoby do radykalnie subiektywistycznej koncepcji ważności prawa, a jej powszechne przyjęcie mogłoby skutkować destabilizacją porządku prawnego (argument moralny).

\footnotetext{
${ }^{38}$ Kelsen, "Law, State and Justice in the Pure Theory of Law", 384.

39 Tamże, 383-384.
} 


\section{Minimum moralne prawa?}

Przyjmując stanowisko pozytywistyczne za uzasadnione, można by powiedzieć, że cele ustanawiania prawa są różne. Ale czy już samo istnienie prawa nie opiera się na jakieś wartości pozaprawnej? „Autorytet prawny nakazuje określone zachowanie człowieka tylko dlatego, że uznaje on je - słusznie czy też nie - za wartościowe [dla wspólnoty prawnej ludzi]"40. Z jednej strony czynnikami, które najbardziej różnicują określone systemy prawne, są właśnie wartości prawne, konstytuowane przez normy prawne ${ }^{41}$. Z drugiej strony, „kiedy rozważymy rozwój, jaki musi przejść prawo od swoich prymitywnych początków aż do poziomu, jaki przedstawia prawo państwa nowoczesnego, możemy, odnosząc się do mającej się ziścić wartości prawa, stwierdzić istnienie pewnej tendencji, która jest wspólna dla porządków prawnych na wyższych etapach rozwoju. Jest to tendencja, która z biegiem czasu w coraz większym stopniu zabraniania wywierania przymusu [fizycznego], używania przemocy wobec człowieka"42. Dotyczy to przymusu nieautoryzowanego przez prawo. Wskazywana przez autora Reine Rechtslehre tendencja polega na monopolizowaniu przymusu przez wspólnotę prawną ${ }^{43}$, tzn. na prawnym określaniu warunków, pod jakimi może zostać użyty przymus. Wynikiem tego procesu jest stosowanie przymusu wyłącznie na podstawie norm prawnych. Jeżeli warunki użycia przymusu określone są przez normy prawne, to $\mathrm{w}$ efekcie zabezpiecza się jednostki przed przymusem pozaprawnym, jaki stosować mogłyby wzajemnie wobec siebie w sytuacji, gdyby zależało to wyłącznie od decyzji. „Kiedy ochrona osiągnie pewien wymiar minimalny, mówimy o zbiorowym - ponieważ zagwarantowanym porządkiem prawnym jako porządek społeczny - bezpieczeństwie" ${ }^{44}$. Dążenie do zapewnienia kolektywnego bezpieczeństwa byłoby wspólną tendencją w rozwoju różnych porządków prawnych. Celem zbiorowego bezpieczeństwa jest pokój, czyli

\footnotetext{
${ }^{40}$ Kelsen, Czysta teoria prawa, 95. Por. Kelsen, Reine Rechtslehre, 34.

${ }^{41}$ Kelsen, Czysta teoria prawa, 99.

42 Tamże, 99. Por. Kelsen, Reine Rechtslehre, 37.

${ }^{43}$ Kelsen, Czysta teoria prawa, 100.

${ }^{44}$ Tamże, 101.
} 
„nieużywanie przemocy fizycznej”" latywnym, nie dotyczy bowiem każdego przypadku użycia przemocy, lecz przemocy niedopuszczalnej prawnie. Prawo posługuje się przymusem (sankcjami), aby osiągnąć stan kolektywnego bezpieczeństwa.

Czy można zatem powiedzieć, że pokój stanowi o moralnej wartości prawa? Zdaniem Kelsena byłby to sąd empiryczny polegający na interpretacji rozwoju prawa. Nie jest ani sądem apriorycznym, którego prawdziwość byłaby bezwzględna, ani sądem deskryptywnym, który potwierdzono w każdym dotychczas badanym przypadku. Stwierdzenie wyżej wspomnianej tendencji nie oznacza, że funkcją prawa jest wyłącznie pacyfikowanie społeczeństwa i monopolizacja przymusu oraz że tylko takie prawo jest "prawem rawdziwym” („słusznym”) ${ }^{46}$. Pokój nie stanowi „minimum moralnego” wspólnego "dla całego prawa" ${ }^{4}$. Wskazanie na omawianą tendencję nie dowodzi, że pokój jest absolutną wartością realizowaną przez prawo. Wskazuje jednakże na to, iż pokój stanowi jedną z ważniejszych wartości prawnych, tj. istotnych dla wspólnoty prawnej. Można zatem domniemywać, że porządek prawny, który nie osiągałby pewnego minimum kolektywnego bezpieczeństwa, tzn. użycie przymusu byłoby całkowicie zdecentralizowane, byłby dysfunkcyjny. W takim systemie wpływ norm prawnych na zachowania adresatów byłby ograniczony, albowiem adresaci prawa nie mogliby być pewni, jakie skutki będzie pociągało zachowanie zgodne lub niezgodne z prawem. Przyjmując, że porządek jest przeciwieństwem potocznie rozumianej anarchii, należy stwierdzić, że to porządek prawny musi prowadzić do pewnego „ładu”, a więc chociażby minimalnego stopnia monopolizacji przymusu.

\footnotetext{
${ }^{45}$ Tamże, 102.

${ }^{46}$ Jak podkreśla Hart, „nie ma żadnych ustalonych zasad zabraniających użycia słowa »prawo« wobec systemu nie posiadającego centralnie zorganizowanych sankcji i są należyte powody (aczkolwiek nie przymus), aby używać wyrażenia "prawo międzynarodowe« w odniesieniu do systemu, który ich nie posiada", Hart, Pojęcie prawa, 269.

${ }^{47}$ Kelsen, Czysta teoria prawa, 103. Otfried Höffe interpretuje tezę Kelsena o zapewnieniu bezpieczeństwa kolektywnego przez prawo jako tezę uzasadniającą, która zawiera zarazem koncepcję sprawiedliwości „poziomu podstawowego”, Otfried Höffe, Sprawiedliwość polityczna. Podstawy krytycznej filozofii prawa i państwa, przeł. Jarosław Merecki (Kraków: Wydawnictwo Znak, 1999), 137-139. Porządek, który w żadnym stopniu nie zapewniałby kolektywnego bezpieczeństwa, nie mógłby być uznany za prawo.
} 
Powstaje zatem pytanie, czy za pomocą kryterium „kolektywnego bezpieczeństwa” można oceniać różne porządki prawne. Czy można oceniać, iż dany porządek $P_{1}$, który w większym stopniu monopolizuje przymus niż porządek $P_{2}$, należy uznać za „lepszy” niż $P_{2}$ ? Czy zmiana normy $N_{1}$ na $N_{2}$ w ramach porządku $P$ jest niesłuszna, gdy zmniejsza poziom „kolektywnego bezpieczeństwa”? Gdyby tak było, kryterium „kolektywnego bezpieczeństwa” byłoby absolutną normą dla sądów wartościujących, dającą zawsze pewny efekt i wykluczającą wpływ nań czynników emotywnych. Jednakże Kelsen nie stawia takiej tezy. Wydaje się, że sposób gwarantowania kolektywnego bezpieczeństwa należy potraktować jako wspomniany wyżej empiryczny kontekst $(K)$, w jakim funkcjonują normy prawne $(N)$, albo skutek ich funkcjonowania. Fakt monopolizowania przymusu $(K)$ w żadnym razie nie uzasadnia $N$, ponieważ nie jest normą. Ważność $N$ opierać się może jedynie na normie, a będzie ona obiektywnie ważna, gdy norma upoważniająca taka będzie. A skoro normy moralne - zgodnie z teorią Kelsena - nie są obiektywne, również prawo nie może opierać się na normach moralnych.

\section{Zakończenie}

Teza o rozdziale prawa i moralności opiera się na specyficznej koncepcji moralności. Kelsen odrzuca możliwość powiązania ważności prawa z moralnością ze względu na subiektywny charakter norm moralnych. Przyjmując omawianą teorię jako punkt odniesienia, można powiedzieć, że przezwyciężenie pozytywistycznej tezy o rozdziale prawa i moralności musiałoby się wiązać z następującymi kwestiami: (a) zakwestionowaniem twierdzenia o wyłącznie emotywnej funkcji wypowiedzi moralnych; (b) podważeniem mocnej opozycji obowiązywania obiektywnej i subiektywnej normy, a także ich subiektywnego i obiektywnego znaczenia. Z perspektywy czystej teorii prawa powiązanie ważności prawa $\mathrm{z}$ jego wartością moralną zagrażałoby możliwości stwierdzenia obiektywnej ważności prawa (co jest istotne dla nauki prawa, której zadaniem byłby opis norm obowiązujących). Można powiedzieć, że odrzucenie tezy o związku prawa i moralności wynika z (a) uznania norm sprawiedliwościowych z subiektywne, (b) pragnienia zapewnienia 
obiektywnej ważności normom prawnym. Emotywny charakter sądów dotyczących sprawiedliwości powoduje, że nie mogą być uznane za podstawę ważności prawa, jeżeli kryterium to ma stanowić obiektywnie ważna norma. A właśnie taki warunek stawia Kelsen w swojej czystej teorii prawa.

\section{Bibliografia}

Ajdukiewicz Kazimierz. 1985. „O sprawiedliwości”. W: Kazimierz Ajdukiewicz, Język i poznanie, tom I. 365-376. Warszawa: Państwowe Wydawnictwo Naukowe.

Ayer Alfred Jules. 1952. Language, Truth and Logic. New York: Dover Publications. Ayer Alfred Jules. 1997. Filozofia w XX wieku, przeł. Tadeusz Baszniak. Warszawa: Wydawnictwo Naukowe PWN.

Finnis John. 2001. Prawo naturalne i uprawnienia naturalne, przeł. Karolina Lossman. Warszawa: Dom Wydawniczy ABC.

Frankena William Klaas. 1939. "The Naturalistic Fallacy”. Mind. New Series 48/192: 464-477.

Hart Herbert Lionel Adolphus. 1958. "Positivism and the Separation of Law and Morals". Harvard Law Review 71/4: 593-629.

Hart Herbert Lionel Adolphus. 1998. Pojęcie prawa, przeł. Jan Woleński. Warszawa: Wydawnictwo Naukowe PWN.

Hart Herbert Lionel Adolphus. 2001. „Wizyta u Kelsena”. W: Herbert Lionel Adolphus Hart, Eseje z filozofii prawa, przeł. Jan Woleński. 290-313. Warszawa: Dom Wydawniczy ABC.

Höffe Otfried. 1999. Sprawiedliwość polityczna. Podstawy krytycznej filozofii prawa i państwa, przeł. Jarosław Merecki. Kraków: Wydawnictwo Znak.

Hospers John. 1975. „Główne teorie metaetyczne”, przeł. Ewa Klimowicz. W: Metaetyka, wybór i red. Ija Lazari-Pawłowska, 34-79. Warszawa: Państwowe Wydawnictwo Naukowe.

Kelsen Hans. 1948. "Law, State and Justice in the Pure Theory of Law". The Yale Law Journal 57/3: 377-390.

Kelsen Hans. 1949. General Theory of Law and State, transl. Anders Wedberg. Cambridge: Harvard University Press.

Kelsen Hans. 1967. „Das Problem der Gerechtigkeit“. W: Hans Kelsen, Reine Rechtslehre (zweite Auflage) mit einem Anhang Das Problem der Gerechtigkeit. 357-444. Wien: Verlag Franz Deuticke.

Kelsen Hans. 1967. Reine Rechtslehre (zweite Auflage) mit einem Anhang Das Problem der Gerechtigkeit. Wien: Verlag Franz Deuticke. 
Kelsen Hans. 1979. Allgemeine Theorie der Normen. Wien: MANZ Verlag. Kelsen Hans. 2014. Czysta teoria prawa, przeł. Rafał Szubert. Warszawa: LexisNexis. MacCormick Neil, Weinberger Ota. 1992. An Institutional Theory of Law. New Approaches to Legal Positivism. Dordrecht-Boston-Lancaster-Tokyo: D. Reidel Publishing Company.

MacIntyre Alasdair. 1996. Dziedzictwo cnoty. Studium z teorii moralności, przeł. Adam Chmielewski. Warszawa: Wydawnictwo Naukowe PWN.

Moore George Edward. 1993. Principia Ethica. Cambridge: Cambridge Univerity Press.

Moser Shia. 1979. "Ethical Non-Cognitivism and Kelsen's Pure Theory of Law”. The University of Toronto Law Journal 29/2: 93-113.

Ott Walter. 1976. Der Rechtspositivismus. Kritische Würdigung auf der Grundlage eines juristischen Pragmatismus. Berlin: Duncker und Humblot.

Pap Arthur. 1975. „Teorie metaetyczne”, przeł. Ewa Klimowicz. W: Metaetyka, wybór i red. Ija Lazari-Pawłowska, 19-33. Warszawa: Państwowe Wydawnictwo Naukowe.

Rachels James. 2009. „Subiektywizm”, przeł. Anna Jedynak. W: Przewodnik po etyce, red. Peter Singer, 480-489. Warszawa: Książka i Wiedza.

Weinberger Ota. 1981. Normentheorie als Grundlage der Jurisprudenz und Ethik. Eine Auseinandersetzung mit Hans Kelsens Theorie der Normen. Berlin: Duncker und Humblot.

Włoch Wojciech. 2013. „Normatywny charakter nauk prawnych w świetle czystej teorii prawa H. Kelsena”, Ruch Filozoficzny 4: 767-773.

Woleński Jan. 1998. „Wstęp”. W: Hart Herbert Lionel Adolphus Hart, Pojęcie prawa, przeł. Jan Woleński, IX-XXIV. Warszawa: Wydawnictwo Naukowe PWN.

Zalewska Monika. 2014. Problem zarachowania $w$ normatywizmie Hansa Kelsena. Łódź: Wydawnictwo Uniwersytetu Łódzkiego.

\section{Abstract \\ Emotivism as a meta-ethical foundation of legal positivism in the context of Hans Kelsen's pure theory of law}

The subject of the article is the problem of meta-ethical assumptions of legal positivism in the context of Hans Kelsen's pure theory of law. Investigating this issue allows us to answer the question regarding the vision of morality underlying the thesis of separation of law from morality, i.e. independence of the application of law from its relations with morality (norms of justice). Indication of the emotional nature of moral statements is Kelsen's main argument. They express only attitudes and preferences, and their validity is only subjective. Therefore, they cannot serve as 
a basis for the validity of legal norms if they are to be perceived as objectively binding. Judgments regarding justice have no objective significance from the validity of law point of view.

Keywords: legal positivism; emotivism; meta-ethics; pure theory of law; separation thesis.

\section{Streszczenie}

\section{Emotywizm jako metaetyczny fundament pozytywizmu prawnego w ujęciu czystej teorii prawa Hansa Kelsena}

Przedmiotem artykułu jest kwestia metaetycznych założeń pozytywizmu prawnego w ujęciu czystej teorii prawa Hansa Kelsena. Zbadanie tego problemu pozwala odpowiedzieć na pytanie, jaka wizja moralności leży u podstaw tezy rozdziału prawa i moralności, tj. niezależności obowiązywania prawa od jego związków z moralnością (normami sprawiedliwościowymi). Głównym argumentem Kelsena jest wskazanie na emotywny charakter wypowiedzi moralnych. Wyrażają one jedynie postawy i preferencje, a ich ważność jest subiektywna. Dlatego nie mogą stanowić podstawy ważności norm prawnych, jeżeli mają być postrzegane jako obiektywnie obowiązujące. Sąd sprawiedliwościowy nie ma z punktu widzenia ważności prawa żadnego znaczenia obiektywnego.

Słowa kluczowe: pozytywizm prawny; emotywizm; czysta teoria prawa; metaetyka; teza o rozdziale. 